\title{
Interaction of Glufosinate and Colletotrichum truncatum on Ammonia Levels and Glutamine Synthetase Activity in Hemp Sesbania
}

\author{
Robert E. Hoagland ${ }^{*}$, C. Douglas Boyette ${ }^{2}$, Robin H. Jordan ${ }^{1}$, Kenneth C. Stetina ${ }^{2}$ \\ ${ }^{1}$ Crop Production Systems Research Unit, USDA-ARS, Stoneville, MS, USA \\ ${ }^{2}$ Biological Control of Pests Research Unit, USDA-ARS, Stoneville, MS, USA \\ Email: ^bob.hoagland@ars.usda.gov
}

How to cite this paper: Hoagland, R.E., Boyette, C.D., Jordan, R.H. and Stetina, K.C. (2018) Interaction of Glufosinate and Colletotrichum truncatum on Ammonia Levels and Glutamine Synthetase Activity in Hemp Sesbania. American Journal of Plant Sciences, 9, 2320-2337.

https://doi.org/10.4236/ajps.2018.911168

Received: September 27, 2018

Accepted: October 26, 2018

Published: October 29, 2018

Copyright $\odot 2018$ by authors and Scientific Research Publishing Inc. This work is licensed under the Creative Commons Attribution International License (CC BY 4.0).

http://creativecommons.org/licenses/by/4.0/

(c) (i) Open Access

\begin{abstract}
The use of microbes and microbial products as bioherbicides has been studied for several decades, and combinations of bioherbicides and herbicides have been examined to discover possible synergistic interactions to improve weed control efficacy. Bioassays were conducted to assess possible interactions of the herbicide glufosinate [2-amino-4-(hydroxymethylphosphinyl) butanoic acid] and Colletotrichum truncatum (CT), a fungal bioherbicide to control hemp sesbania (Sesbania exaltata)]. Glufosinate acts as a glutamine synthetase (GS) inhibitor that causes elevated ammonia levels, but the mode of action of CT is unknown. GS has also been implicated in plant defense in certain plant-pathogen interactions. The effects of spray applications of glufosinate $(1.0 \mathrm{mM})$ orbioherbicide $\left(8.0 \times 10^{4}\right.$ conidia $\left.\mathrm{ml}^{-1}\right)$, applied alone or in combination were monitored ( $88 \mathrm{~h}$ time-course) on seedling growth, GS activity and ammonia levels in hypocotyl tissues under controlled environmental conditions. Growth (elongation and fresh weight) and extractable GS activity were inhibited in tissues by glufosinate and glufosinate plus CT treatments as early as $16 \mathrm{~h}$, but CT treatment did not cause substantial growth reduction or GS inhibition until after $\sim 40 \mathrm{~h}$. Generally, ammonia levels in hemp sesbania tissues under these various treatments were inversely correlated with GS activity. Localization of hemp sesbania GS activity on electrophoretic gels indicated a lack of activity after $30 \mathrm{~h}$ in glufosinate and glufosinate plus CT-treated tissue. Untreated control tissues contained much lower ammonia levels at 24,64 , and $88 \mathrm{~h}$ after treatment than treatments with CT, glufosinate or their combination. CT alone caused elevated ammonia levels only after $64-88 \mathrm{~h}$. Glufosinate incorporated in agar at $0.25 \mathrm{mM}$ to $2.0 \mathrm{mM}$, caused a $10 \%-45 \%$ reduction of CT colony radial growth, compared to fungal growth on agar without glufosinate, and the herbicide also inhibited spo-
\end{abstract}


rulation of CT. Although no synergistic interactions were found in the combinations of CT and glufosinate at the concentrations used, further insight on the biochemical action of CT and its interactions with this herbicide on hemp sesbania was achieved.

\section{Keywords}

Bioherbicide, Hemp Sesbania, Glutamine Synthetase, Ammonia, Glufosinate, Colletotrichum truncatum

\section{Introduction}

Hemp sesbania [Sesbania exaltata (Raf.) Rydb. ex A.W. Hill], (native to U.S.) a vigorous, nodulating, epigeal, leguminous weed in soybean [Glycine max (L.) Merr.], cotton (Gossypium hirsutum L.) and rice (Oryza sativa L.), can attain a height of $3 \mathrm{~m} \mathrm{[1]}$ and was deemed one of the 10 most troublesome weeds in the southern U.S. [2]. It can reduce crop yield through shading and competition [3] and has high reproductive capacity (up to 21,000 seeds plant ${ }^{-1}$ ) [4]. No pre- or post-emergent herbicide can provide season-long control of hemp sesbania [5]. This weed exhibits some tolerance to glyphosate [ $N$-(phosphonomethyl)glycine] [6] [7] [8], but glufosinate[2-amino-4-(hydroxymethylphosphinyl)butanoic acid] can provide effective control [9] [10]. Glufosinate is the ammonium salt of phosphinothricin (a naturally produced tripeptide), which is the active ingredient of bialaphos derived from non-phytopathogenic species in the genus Streptomyces [11].

Biological weed control using plant pathogens (bioherbicides) has received attention by academic and industrial researchers for quite some time [12]-[19]. Colletotrichum truncatum is a plant pathogenic fungus with bioherbicidal activity for controlling hemp sesbania [20] [21] [22] [23] [24]. However, as with most foliar pathogens, spores (conidia) of this fungus require sustained free-moisture, or a dew period to promote spore germination, establish infection and cause disease [20] [21]. Hemp sesbania was effectively controlled in soybean by $C$. truncatum conidia formulated in an invert emulsion (water-in-oil) [21]. Greenhouse experiments showed that oil-in-water emulsions of unrefined corn oil and C. truncatum spore suspensions could reduce the dew period requirements for maximum weed infection and mortality of hemp sesbania, and thus delay the requirement for free-moisture [25]. Unrefined corn oil (but not refined corn oil) was found to stimulate germination of $C$. truncatum spores [26].

Various attempts to improve the utility and efficacy of bioherbicides (especially under field environments) have been implemented. One method to achieve this has been to combine a bioherbicide with an herbicide to possibly produce either an additive, or synergistic effect on weed control [27] [28] [29]. Use of an herbicide for possible synergistic interactions with a bioherbicide could be realized as generally occurring in two ways, i.e., through direct action of 
the herbicide on its specific biochemical target site, or via secondary herbicidal effects that may weaken weed biochemical defenses against pathogen attack. However, many herbicides exhibit toxicity towards bioherbicides, caused by either the active ingredient and/or the various adjuvants, surfactants, etc. (inert ingredients) formulated in the commercial products. Combinations of glyphosate and several bioherbicides have resulted in additive or synergistic action on the control of weeds. Synergistic interactions of the herbicide glyphosate and Myrothecium verrucaria on several weeds have been documented [30] [31] [32] and $C$. truncatum combined with glyphosate interacted synergistically to control hemp sesbania [33]. Glyphosate and the bioherbicide, Alternaria cassiae applied to sicklepod resulted in a synergistc interaction [34]. Synergy of two bacterial plant pathogens with glufosinate was also demonstrated in greenhouse and field studies [29], but results of synergy studies of glufosinate and Pyricularia setariae [bioherbicide for green foxtail (Setaria virdis)] were variable [35]. Furthermore, some commercial glyphosate products are toxic to certain bioherbicides.

The enzyme glutamine synthetase (GS) plays a pivotal role in nitrogen metabolism and is responsible for the condensation of ammonium ion and glutamate to produce glutamine. This metabolic reaction is vital for glutamine synthesis and for ammonia re-assimilation and detoxification in plants. Glufosinate, originally isolated from Streptomyces species as phosphinothricin [11], inhibits GS and causes toxic levels of ammonia to accumulate in plants. Plant injury symptoms caused by glufosinate action develop more rapidly in light-grown plants than in dark-grown plants [36].

In our early research with hemp sesbania seedlings treated with $C$. truncatum, an odor (somewhat reminiscent of biological ammoniacal compounds) was noted during the late stages of the disease progression cycle (unpublished observation). This was especially apparent when working with plants in small environmental cabinets, and it occurred when plants were treated under either continuous light or dark growth conditions. Because, 1) glufosinate can control hemp sesbania (and its mode of action causes ammonia toxicity via GS inhibition), 2) C. truncatum causes ammonia-like odors in hemp sesbania, and 3) bioherbicide interactions with herbicides may possibly result in beneficial additive or synergistic action for weed control, our working hypothesis for this project evolved into: "Does $C$. truncatum affect nitrogen metabolism in hemp sesbania through inhibition of GS (causing toxic ammonia levels); and if so, it is possible that glufosinate and $C$. truncatum would act synergistically with respect to control of this weed". Thus, our objectives were to test for these possible interactions by a series of growth, GS assay, and ammonia analysis experiments using hemp sesbania treated with $C$. truncatum, glufosinate, and their combination under controlled environmental conditions.

\section{Materials and Methods}

\subsection{Sources of Seeds and Chemicals}

Glufosinate (Basta) (99.8\% pure, free acid) was a product of Plant Media (Divi- 
sion of BioWorld; Dublin, OH, USA). Hemp sesbania seeds were collected from plants grown in a field nursery at USDA-ARS, CPSRU, Stoneville, MS. Potato dextrose agar (PDA) was a Difco product (Difco Laboratories, Detroit, MI, USA). All other chemicals were of reagent grade or higher purity.

\subsection{Source and Culture of $C$. truncatum}

A single-spore strain of C. truncatum (NRRL No. 18434), originally isolated from infected hemp sesbania collected near Stoneville, MS, USA [20], was used throughout these experiments. The fungus, which had been preserved in capped test tubes containing sterilized soil [37], was grown for 5 to 7 days on PDA in 10 $\mathrm{cm}$ plastic Petri dishes. The dishes were incubated (Precision Scientific Inc., Chicago, IL, USA) on open-mesh wire shelves $\left[25^{\circ} \mathrm{C}\right.$, cool, white fluorescent lighting (12 h photo-period) providing $165 \mu \mathrm{mol} \mathrm{m}^{-2} \mathrm{~s}^{-1}$. C. truncatum spores (conidia) were harvested by rinsing the conidia from the culture plates with water and straining through two layers of cheesecloth. Conidial densities were determined with hemacytometers and dilutions were made in sterile, distilled water. Conidia used in these tests were no older than $4 \mathrm{~h}$ after collection from PDA plates.

\subsection{Culture of Plant Seedlings}

Hemp sesbania seeds were mechanically scarified, then surface sterilized (5\% sodium hypochlorite; $10 \mathrm{~min}$ ) and rinsed thoroughly with distilled water. Seeds were planted in paper toweling as described previously [38] and placed in a high-humidity (100\% relative humidity) chamber under continuous darkness $\left(78^{\circ} \mathrm{C}\right)$. After seed germination and seedling growth for 3 days under these conditions, seedlings with uniform hypocotyl lengths $(10-13 \mathrm{~mm})$ were selected and transferred to fresh paper toweling and placed in a high-humidity chamber under continuous light $\left(80^{\circ} \mathrm{C}, 170 \mu \mathrm{Em}^{-2} \mathrm{~s}^{-1}\right)$ for $24 \mathrm{~h}$ prior to treatment, to acclimate seedlings to the environmental treatment conditions used in these tests.

\subsection{Spray Application of Bioherbicide and Herbicide}

After $24 \mathrm{~h}$ growth under continuous light (seedlings in cotyledonary growth stage), the plants were divided into four treatment groups for spray applications: control $=$ water; $C$. truncatum $\left(8.0 \times 10^{4}\right.$ conidia $\left.\mathrm{ml}^{-1}\right)$; glufosinate $(1.0 \mathrm{mM})$; and $C$. truncatum $\left(8.0 \times 10^{4}\right.$ conidia $\left.\mathrm{ml}^{-1}\right)$ plus glufosinate $(1.0 \mathrm{mM})$. The glufosinate-treated groups were sprayed at the same time, and the herbicide spray allowed to partially dry ( $\sim 30 \mathrm{~min})$ prior to application of conidia to the plants in the glufosinate plus conidial treatments. Plants were spray-inoculated with conidial suspensions of aqueous preparations of $C$. truncatum and/or glufosinate using hand-held aerosol sprayers (Spra-tool Power Pack, Aervoe Industries, Inc., Gardnersville, NV). Spray delivery rates were $\sim 200 \mathrm{~L} \cdot \mathrm{ha}^{-2}$ [39]. After all spray applications were made, the plants were placed in a high-humidity chamber for $16 \mathrm{~h}$ at $78^{\circ} \mathrm{C}$ under continuous darkness and then plants were transferred to continuous light in an environmental chamber $(28 \mathrm{C}, 600 \mu \mathrm{E})$ for the duration of the tests. 


\subsection{Growth Effects Caused by Treatments}

At various intervals over a 0 to $88 \mathrm{~h}$ time-course, hypocotyls were harvested, weighed and their lengths measured, and then the tissue was frozen $\left(-80^{\circ} \mathrm{C}\right)$ for further analysis. This plant organ was used for analysis in subsequent tests: $\left(\mathrm{NH}_{3}\right.$ content, extractable GS activity, protein levels, PAGE electrophoresis, in-gel GS localization and in-gel protein analysis), as described below.

\subsection{Ammonia Assay of Hypocotyl Tissue}

Frozen $\left(-80^{\circ} \mathrm{C}\right)$ hypocotyls from the treated plants were ground/homogenized in cold phosphate buffer (0.05 M, pH 7.0) using chilled mortar/pestles. Each homogenate was collected and centrifuged ( $\left.15 \mathrm{~min}, 20,000 \mathrm{x} \mathrm{g}, 4^{\circ} \mathrm{C}\right)$. The supernatant was used to quantify the ammonia and ammonium ion concentration in hemp sesbania hypocotyl tissue using a salicylate-nitroprusside assay [40].

\subsection{Assay of Extractable Glutamine Synthetase}

Weighed portions of frozen $\left(-80^{\circ} \mathrm{C}\right)$ hypocotyls from the treated plants were ground/homogenized with extraction buffer (100 mM Tris base, 1 mM EDTA, 1 $\mathrm{mM} \mathrm{MgCl} 2$ and $10 \mathrm{mM} \beta$-mercapto-ethanol, $\mathrm{pH} \mathrm{7.0)} \mathrm{in} \mathrm{chilled} \mathrm{mortar/pestles}$ and the homogenates were collected and centrifuged $\left(20 \mathrm{~min}, 21,000 \mathrm{x} \mathrm{g}, 4^{\circ} \mathrm{C}\right)$. The supernatants were used directly to determine total GS activity, as measured via the $\gamma$-transferase reaction [41]. The assay mixture contained $100 \mathrm{mM}$ Tris base, $1.33 \mathrm{mM}$ EDTA, $20 \mathrm{mM} \mathrm{MgSO}_{4}, 20 \mathrm{mM}$ sodium arsenate, $0.5 \mathrm{mM}$ ADP, 25 $\mathrm{mM}$ hydroxylamine and $50 \mathrm{mM} \mathrm{L}$-glutamine, adjusted to $\mathrm{pH}$ 7.0. The mixture was equilibrated in a 96 -well plate at $30^{\circ} \mathrm{C}$ for $5 \mathrm{~min}$, and the reaction was initiated by adding the enzyme extract. After appropriate times, the reaction was stopped with $100 \mu \mathrm{l}$ of stop reagent $\left[5.5 \% \mathrm{FeCl}_{3} \cdot 6 \mathrm{H}_{2} \mathrm{O}(\mathrm{w} / \mathrm{v}), 2 \%\right.$ trichloroacetic acid (w/v), and $2.1 \%$ conc. $\mathrm{HCl}$ ], followed by centrifugation $(5 \mathrm{~min} ; 10,000 \times \mathrm{g}$ ) to remove any precipitate. The product ( $\gamma$-glutamylhydroxamate) was measured spectrophotometrically $\left(\mathrm{A}_{535} \eta \mathrm{m}\right)$ using a plate reader (BioTek Synergy HT, Winooski, VT), and a standard curve of $\gamma$-glutamylhydroxamate concentration was generated. A reaction mixture without GS enzyme served as the blank. Protein in extracts was quantified spectrophotometrically $\left(\mathrm{A}_{660} \eta \mathrm{m}\right)$ (Pierce ${ }^{\mathrm{TM}} 660 \mathrm{\eta m}$ Protein Assay; Pierce Biotechnology, Rockford, IL, USA).

\subsection{PAGE-Electrophoresis}

Aliquots of the protein samples were loaded on gels (Criterion TGX, $4 \%-20 \%$, Bio-Rad), and were run $180 \mathrm{~min}$ at constant voltage $\left(200 \mathrm{~V}, 4^{\circ} \mathrm{C}-5^{\circ} \mathrm{C}\right)$. Molecular weight marker protein standards (NativeMark ${ }^{\mathrm{TM}}$; Thermo Fisher Scientific, Waltham, MA, USA) were electrophoresed in separate lanes on each gel. Gels were stained using Biosafe Coomassie stain (Bio-Rad Corp., Van Nuys, CA, USA), de-stained and then photographed. Two sets of the extracted samples (20 $\mu \mathrm{g}$ ) from the four treatments were loaded on a $12.5 \%$ Tris- $\mathrm{HCl}$ gel (Bio-Rad, Van Nuys, CA). Standard protein markers were also included in separate lanes 
and the gel electrophoresed for $45 \mathrm{~min}$ at constant voltage $\left(200 \mathrm{~V} ; 4^{\circ} \mathrm{C}-5^{\circ} \mathrm{C}\right)$. After electrophoresis the gels were removed and cut. Half of the gel was stained with Biosafe Coomassie stain (Bio-Rad) as described and half was used for in-gel localization of GS enzyme activity (see below).

\section{Localization of Glutamine Synthetase Activity on Gels}

GS activity was detected using the $\gamma$-glutamyl-transferase reaction mixture previously described, except that the $\mathrm{pH}$ was increased to 7.5. Gels were removed from the PAGE apparatus, rinsed in cold 0.1 M-Tris/HCl buffer, $\mathrm{pH} 7.5$, and then incubated in the assay reaction mixture (see above) for 45 to $60 \mathrm{~min}$ at $30^{\circ} \mathrm{C}$. The gel was then incubated in ferric chloride reagent $\left[3.3 \% \mathrm{FeCl}_{3} \cdot 6 \mathrm{H}_{2} \mathrm{O}\right.$ $(\mathrm{w} / \mathrm{v}), 2 \%$ trichloroacetic acid $(\mathrm{w} / \mathrm{v})$, and $0.25 \mathrm{~N} \mathrm{HCl}$ ] for up to $15 \mathrm{~min}$ to allow red-brown colored bands to develop. Since the colored activity bands fade, the mobility (location) was recorded and photographed soon after the appearance of color. After photographing, the gel was also imaged using a Bio-Rad ChemiDoc MP imager with Image Lab (Version 6.0) software (Bio-Rad Corp., Van Nuys, CA).

\subsection{Toxicity Tests of Glufosinate on $C$. truncatum}

To examine possible toxic effects of glufosinate on $C$. truncatum, the herbicide was incorporated into PDA to achieve various concentrations (0 to $2.0 \mathrm{mM})$ in this growth medium. Aliquots $(3 \mu \mathrm{l})$ of $C$. truncatum conidia $\left(5 \times 10^{4}\right.$ conidia $\mathrm{ml}^{-1}$ ) were pipetted onto the center agar surface of each concentration and plates were placed in an incubator (Precision Scientific Inc.) at $28^{\circ} \mathrm{C}$ under a $12 \mathrm{~h}$ alternating light-dark cycle. The test was set up in triplicate and radial growth (colony diameter) of each colony was measured at $24 \mathrm{~h}$ intervals over a 5-day growth period.

\subsection{Statistics}

A randomized complete block experimental design with four replications was utilized in these experiments. All tests were performed in triplicate and experiments were repeated in time. Means from duplicate tests were pooled and values are presented with standard error of means (SE).

\section{Results and Discussion}

\subsection{Growth Effects of Glufosinate and C. truncatum on Hemp Sesbania}

The analysis of growth of hemp sesbania seedlings over the time course under continuous light, showed that spray application of C. truncatum $\left(8.0 \times 10^{4}\right.$ conidia $\mathrm{ml}^{-1}$ ) caused no major effects on hypocotyl elongation, but glufosinate treatment $(1.0 \mathrm{mM})$ caused dramatic reductions in elongation of this plant organ as early as $16 \mathrm{~h}$ after treatment (Figure $1(\mathrm{a})$ ). This indicated that the herbicide is rapidly absorbed into the seedling tissues and it essentially caused a cessation of 
growth. Elongation caused by $C$. truncatum combined with glufosinate was generally equal to the effect caused by glufosinate alone. Fresh weight of this plant organ increased slightly with time in the untreated control plants over the time course, as did this parameter for the $C$. truncatum treatment, where it was unchanged until about $40 \mathrm{~h}$ after treatment when there was a strong decline (Figure 1(b)). This sharp decrease correlated with the beginning of hypocotyl collapse caused by the pathogen. Figure 2(a) and Figure 2(b) visually demonstrate these effects at $48 \mathrm{~h}$ and $80 \mathrm{~h}$ after treatment.

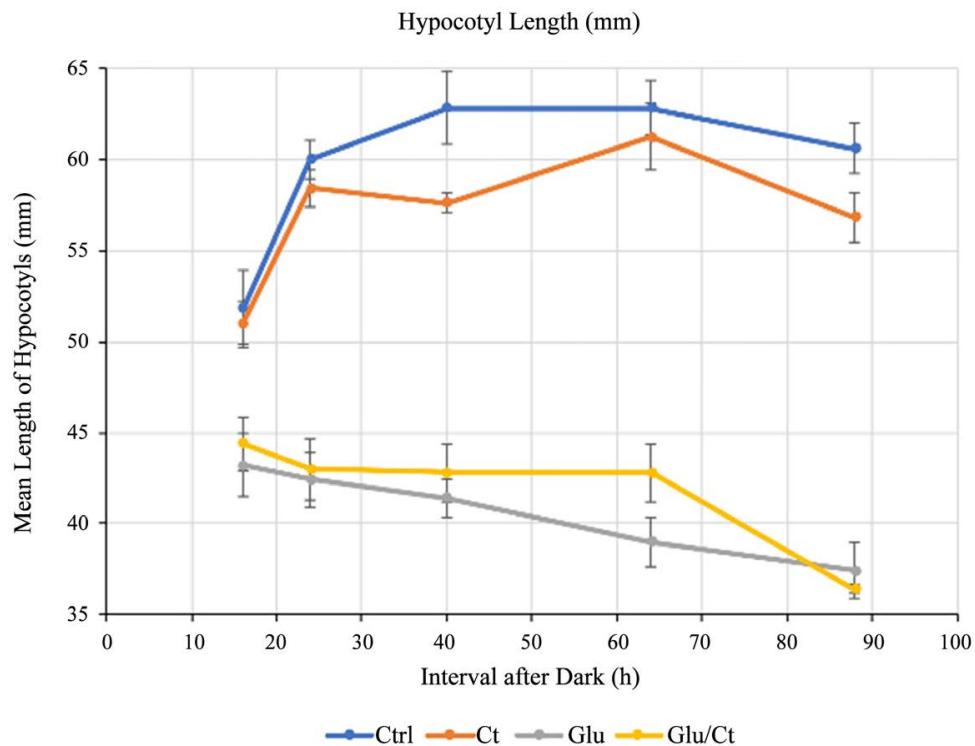

(a)

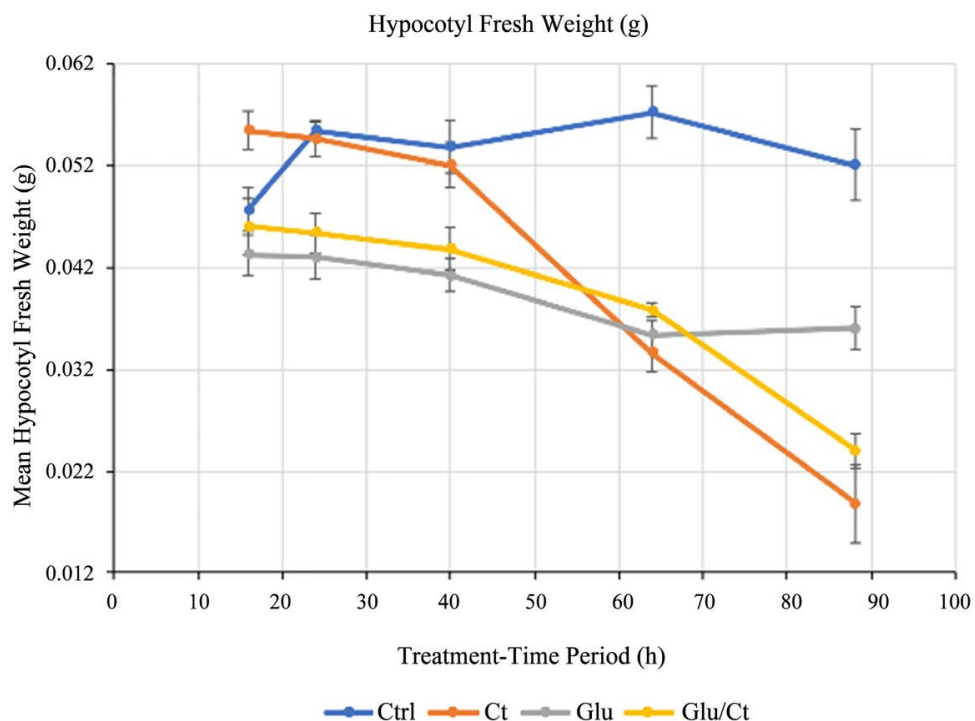

(b)

Figure 1. Growth effects of spray applications of C. truncatum $\left(8 \times 10^{4}\right.$ conidia $\left.\mathrm{ml}^{-1}\right)$, glufosinate $(1.0 \mathrm{mM})$, and the combination of $C$. truncatum and glufosinate on hemp sesbania hypocotyl elongation $(\mathrm{mm})(\mathrm{a})$, and fresh weight $(\mathrm{g})$ accumulation (b) over an 88-h time course. Mean values for hypocotyl lengths and fresh weights represent 5 plant organs for each data point, \pm SE. 


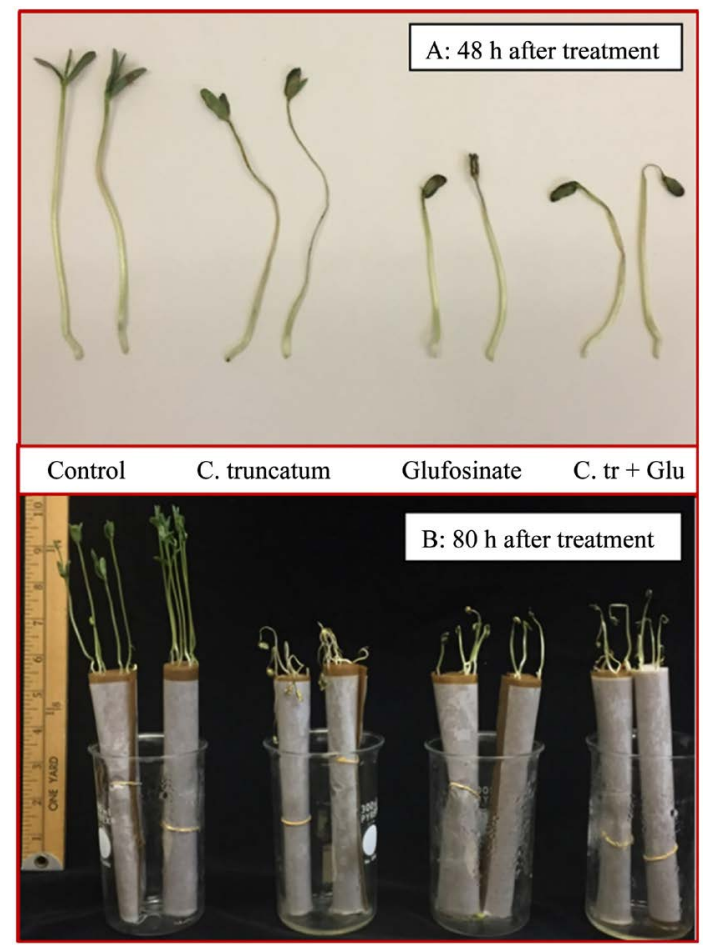

Figure 2. Photograph showing comparative effects of spray applications of $C$. truncatum $\left(8 \times 10^{4}\right.$ conidia $\left.\mathrm{ml}^{-1}\right)$, glufosinate $(1.0 \mathrm{mM})$, and the combination of $C$. truncatum and glufosinate on hemp sesbania seedlings, $48 \mathrm{~h}$ (a) and $80 \mathrm{~h}$ (b) after application.

\subsection{Glutamine Synthetase Assay and Localization on PAGE Gels}

C. truncatum treatment of hemp sesbania did not cause significant effects on GS activity until after $40 \mathrm{~h}$, a time when hypocotyls lose their structural integrity (unable to support themselves) during the initial stages of collapse (Figure 3). This effect has been previously described in another study [38]. At $64 \mathrm{~h}$ after treatment, the pathogen lowered GS activity by about $10 \%$, but at $88 \mathrm{~h}$, GS was inhibited by $\sim 65 \%$. Glufosinate and the glufosinate plus $C$. truncatum treatments both caused substantial inhibition of GS throughout the 16 to $88 \mathrm{~h}$ period. However, GS activity in the herbicide/pathogen combination treatment was slightly higher than the glufosinate alone treatment at most time points.

Electrophoretic separation of the hemp sesbania proteins after the various treatments offered the chance to visually localize GS activity on the gels and to qualitatively compare the activity and mobility of GS with that of other proteins (Figures 4(a)-4(c)). Figure 4(a) depicts a color image of GS activity as affected by the various treatments. Activity was present in the 0 -time control, the $30-\mathrm{h}$ control and in the $C$. truncatum-treated hypocotyls, $30 \mathrm{~h}$ after treatment. However, no activity was present in the glufosinate- or in the glufosinate plus $C$. truncatum-treated tissue, which indicated the enzyme was inhibited. As expected, no other proteins (standard markers and hemp sesbania proteins) exhibited activity (Figure 4(a) and Figure 4(b)). These red-brown color bands that fade rapidly, were subsequently imaged, to corroborate results (Figure 4(b)). A matching gel, stained with protein stain (Coomassie) showed the location of the 
GS protein (red arrow), as well as the profiles of other proteins from the treatments (Figure 4(c)).

Glutamine Synthetase Activity \% of Control

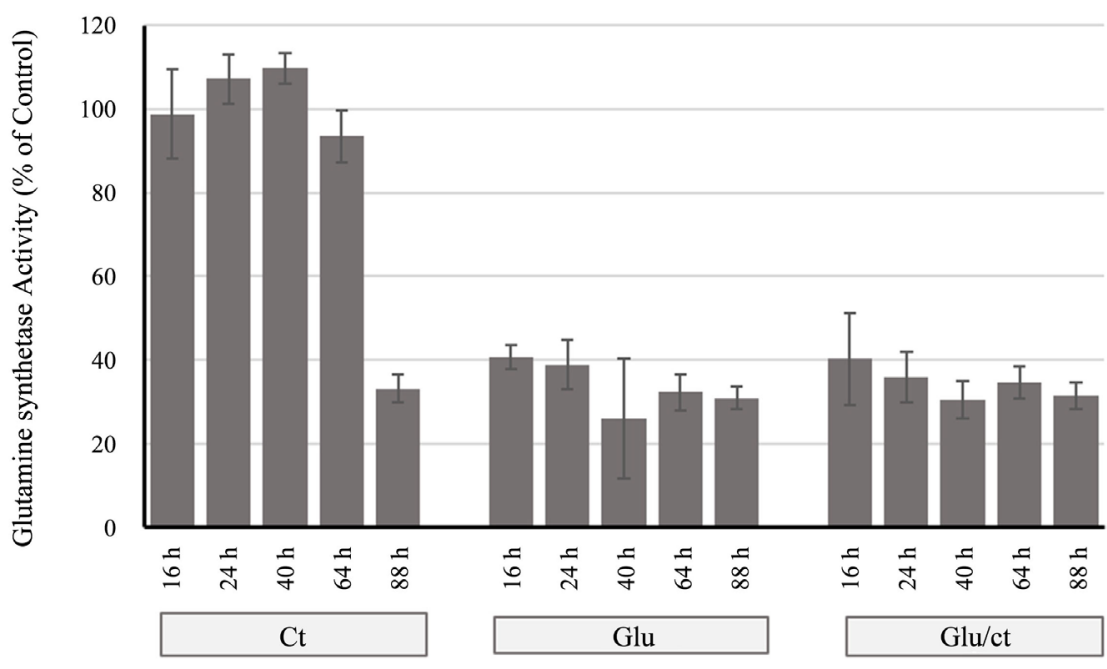

Time After Treatment (h)

Figure 3. Extractable glutamine synthetase activity from hemp sesbania hypocotyls as affected by treatment of $C$. truncatum $\left(8 \times 10^{4}\right.$ conidia $\left.\mathrm{ml}^{-1}\right)$, glufosinate $(1.0 \mathrm{mM})$, and the combination of $C$. truncatum and glufosinate, $30 \mathrm{~h}$ after treatment. The $0 \mathrm{~h}$ control value is the activity before treatment was initiated. Data are expressed as percentage of untreated control, \pm SE.
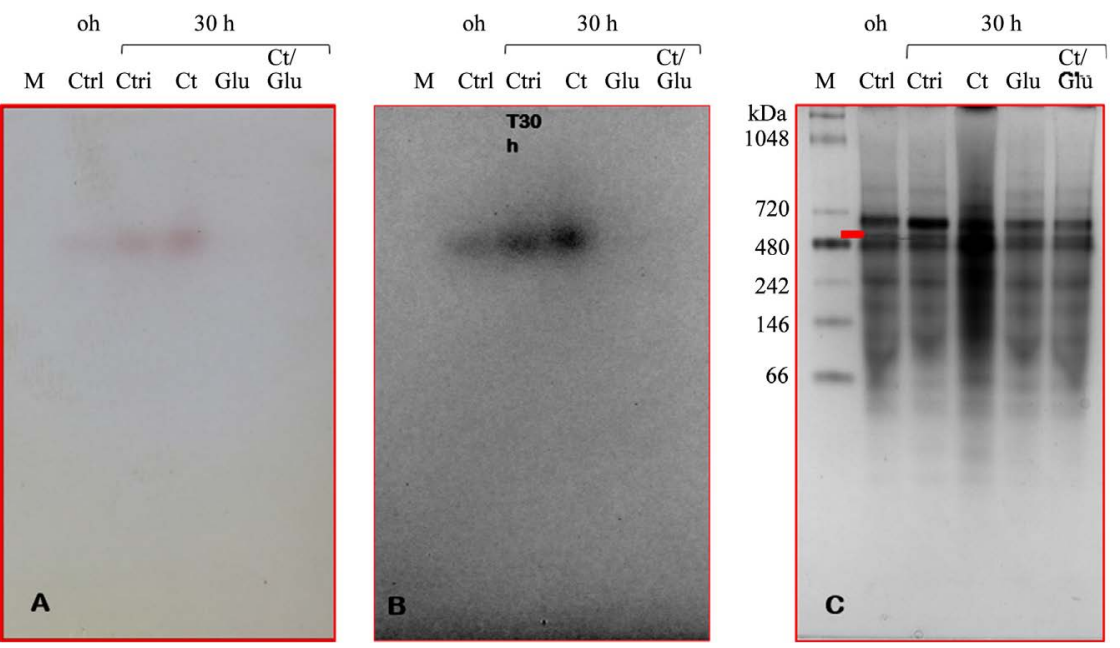

Figure 4. Localization of glutamine synthetase extracted from hemp sesbania hypocotyls on PAGE gels as affected by treatment with $C$. truncatum $\left(8 \times 10^{4}\right.$ conidia $\left.\mathrm{ml}^{-1}\right)$, glufosinate $(1.0 \mathrm{mM})$, and the combination of $C$. truncatum and glufosinate, after $30 \mathrm{~h}$ in the time course. Aligned gels represent: $A=G S$ activity shown in color photograph of $\mathrm{FeCl}_{3}$ :hydroxamatecomplex (enzyme product) formed on PAGE gel after 70 min incubation in GS substrate reaction mixture; $\mathrm{B}=$ image of $\mathrm{FeCl}_{3}$ :hydroxamate complex formed in PAGE gel using a Bio-Rad ChemiDoc MP imager; $\mathrm{C}=$ protein stain (Coomassie) of PAGE gel, showing localization (red arrow) of GS protein. $\mathrm{M}=$ marker protein lane, with molecular weights $(\mathrm{kDa})$ indicated on Figure $4(\mathrm{c})$ y-axis.(Note: marker proteins and other proteins are not visible in $4 \mathrm{~A}$ and $4 \mathrm{~B}$ because they lack $\mathrm{GS}$ activity). 


\subsection{Ammonia Levels in Hypocotyl Tissue}

Generally, ammonia levels in hemp sesbania tissues under these various treatments (Figure 5) were inversely correlated with the GS activity (Figure 3 ). The untreated control tissues contained much lower ammonia levels at 24, 64, and 88 h after treatment than the $C$. truncatum, glufosinate or the combination of the herbicide and bioherbicide treatments. $C$. truncatum alone caused elevated ammonia levels only at 64 and $88 \mathrm{~h}$ after treatment, and this is during tissue collapse.

\subsection{Toxicity Tests of Glufosinate on C. truncatum}

The toxicity of various concentrations of glufosinate (0 to $2.0 \mathrm{mM}$ ), incorporated into PDA was examined on $C$. truncatum over a 144-h time-course. After inoculation on PDA dishes, radial growth of $C$. truncatum colonies was found to be negatively affected by the herbicide at all herbicide concentrations tested (Figure 6). When measured at the end of the time-course, the $0.25 \mathrm{mM}, 1.0 \mathrm{mM}$ and $2.0 \mathrm{mM}$ glufosinate concentrations caused a $10 \%, 25 \%$ and $45 \%$ reduction of colony diameter, respectively as compared to fungal growth on PDA without glufosinate. Furthermore, glufosinate inhibited sporulation of the bioherbicide in this growth bioassayon PDA as noted by lack of dark pigmentation (probably melanin) on culture surfaces (Figure 6).

Glufosinate is produced naturally by several species of the Streptomycetaceae family (gram-positive bacteria) and has antibacterial, antifungal and potent herbicidal properties [11]. Antibacterial activity is generally weak since many bacteria can metabolize (detoxify) this compound [42], although the herbicide was

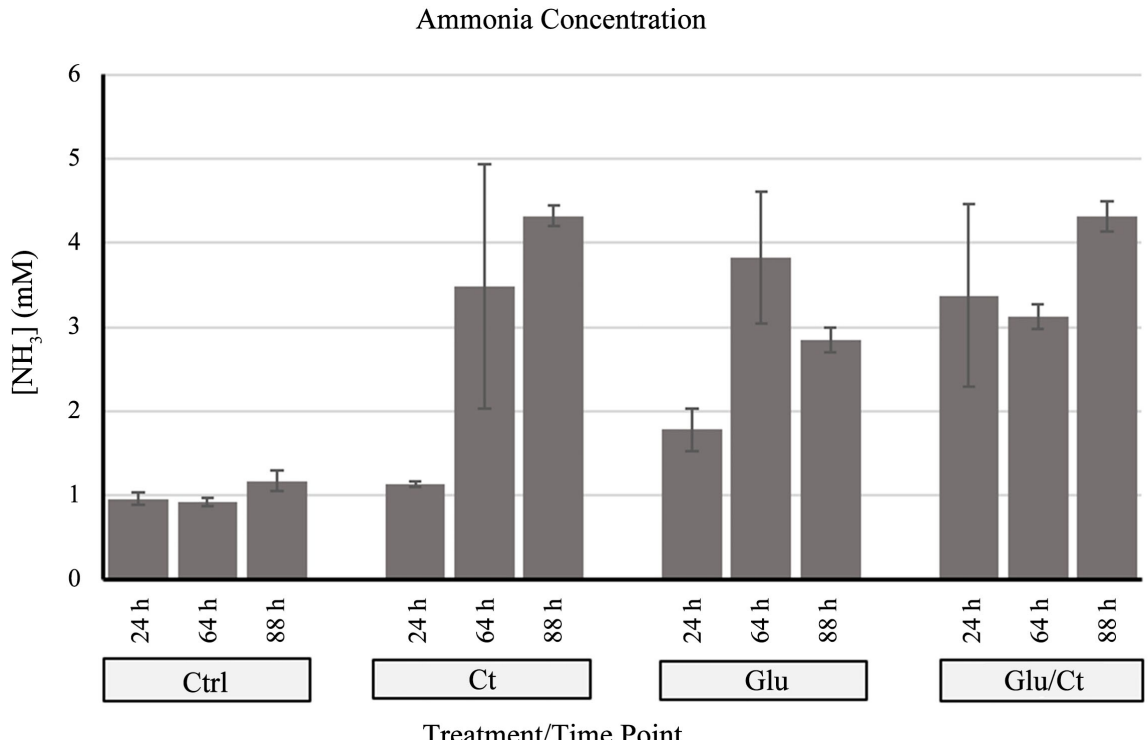

Figure 5. Effects of spray applications of $C$. truncatum $\left(8 \times 10^{4}\right.$ conidia $\left.\mathrm{ml}^{-1}\right)$, glufosinate $(1.0 \mathrm{mM})$, and the combination of $C$. truncatum and glufosinate on ammonia content in hypocotyls of hemp sesbania at several time points during the 88 -h time course. Histogram bars represent means of triplicate values, \pm SE. 

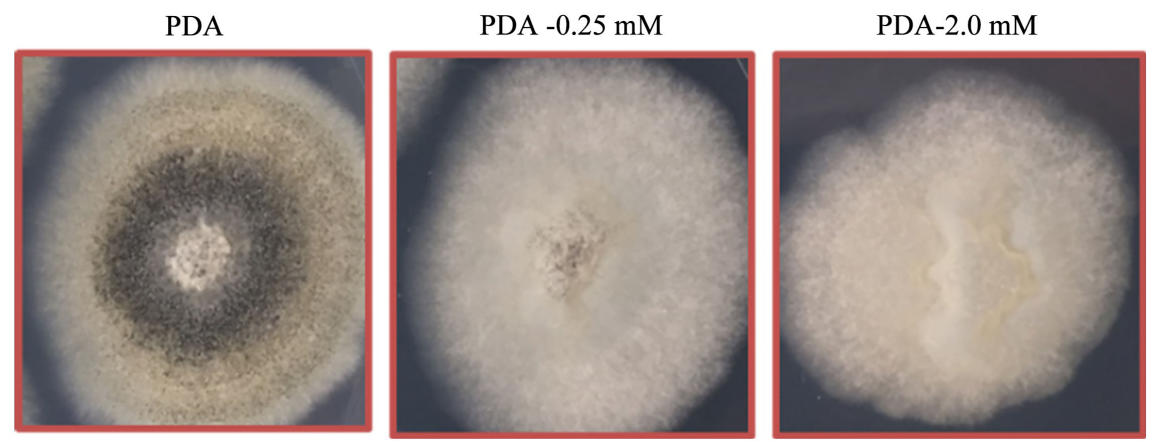

Figure 6. Effects of glufosinate on radial growth of $C$. truncatum colonies on PDA supplemented with varying concentrations of glufosinate (0 to $2.0 \mathrm{mM})$ in Petri dishes, after 5 days growth. The centers of each dish were inoculated with $C$. truncatum conidia and radial growth was measured over a 5-day growth period as described in M \& $M$.

antibacterial against $P$. syringae pv. glycinea [soybean (Glycine max) blight disease] [43]. Many reports are related to the activity of glufosinate on fungi. Similar to the present results, glufosinate also inhibited spore production of Penicillium expansum, a fungal pathogen (blue mold) of fruits and vegetables [44]. Furthermore, low doses of glufosinate in bean (Phaseolus vulgaris) roots resulted in enhanced sporangial germination of the fungal pathogen, Pythium ultimum [45]. At a low concentration $\left(100 \mu \mathrm{g} \cdot \mathrm{mL}^{-1}\right)$, the herbicide inhibited appressorium formation of Magnaporthe grisea [rice (Oryza sativa) blast disease] and Cochliobolus miyabeanus (brown spot disease in rice), but conidial germination was unaffected. Similar results were reported for M. grisea in vitro [46] [47]. It was also antifungal against pathogens of grapes (Vitis spp.) [44] [48]. Glufosinate significantly inhibited mycelial growth of Rhizoctonia solani (sheath blight disease) and S. homoeocarpa (dollar spot disease) infecting bentgrass (Agrostis palustris) [49] and also inhibited some beneficial plant soil fungi and bacteria [50]. Several disease-causing plant fungi were among the most resistant to glufosinate [42]. Compatibility tests of $C$. truncatum (different strain than used in present studies) conidia with herbicides in vitro, resulted in a wide range of effects on conidial germination with the different herbicides [51]. In that report, glufosinate caused only a slight inhibition of germination after incubation of conidia for $24 \mathrm{~h}$ in a $1 \mathrm{X}$ concentration of commercially formulated herbicide product.

Our studies on C. truncatum presented here centered around ammonia, i.e., increased ammonia levels produced and/or caused by the fungus, and ammonia produced in hemp sesbania plants due to the inhibition of GS by glufosinate. We also anticipated a possible synergistic interaction of this pathogen and glufosinate. It should be considered that, mechanisms other than GS inhibition can also lead to ammonia production in plants. For example, phenylalanine ammonia lyase (PAL), amidases, amidohydrolases, and nitralases [52] [53]. These enzymes can produce ammonia as a product via catalysis of their respective substrates. Furthermore, these enzymes have been implicated in plant-microbe interactions related to defense. GS has been implicated as having a defense role in plants-pathogen interactions and may play a role in the NO signaling response 
in root nodules by contributing to the antioxidant defenses [54]. Cytosolic GS genes were induced following pathogen infection in tobacco (Nicotiana tabacum) [55] and similar induction occurred in Arabidopsis following infectivity by E. amylovora [56]. Glutamine levels have been also correlated with the activation of defense responses in plants [57].

PAL catalyzes the non-oxidative conversion of phenylalanine to cinnamic acid (precursor of the phenylpropanoids) and ammonia. Also, amidases (acylamide amidohydrolases, EC 3.5.1.4) catalyze the hydrolysis of carboxylic amide bonds to liberate carboxylic acids and ammonia. Presently it is unknown if these defense enzymes are involved in the CT and glufosinate interactions as studied here, but it would be a large and interesting undertaking to study.

Weed defense mechanisms against pathogens are important to bioherbicidal efficacy and to interactions of bioherbicides and herbicides. PAL activity can increase dramatically in response to various stimuli (light, mechanical injury, action of some chemicals, elicitors, and challenge by pathogens) [58]. This increased enzyme activity leads to increased production of cinnamic acid, phenolic products and phytoalexins, some of which are toxic to bacteria and fungi. Another product of PAL catalysis is ammonia. This increased enzyme activity leads to increased production of cinnamic acid, phenolic products and phytoalexins, some of which are toxic to bacteria and fungi. Another product of PAL catalysis is ammonia. Furthermore, PAL was suggested as a target site for herbicides [59] and PAL activity was shown to be elevated or inhibited by various herbicides [60]. The fungal pathogen Alternaria cassiae, has bioherbicidal activity against sicklepod (Senna obtusifolia) [61] [62] [63], and alters phenylpropanoid metabolism in this weed [64]. PAL activity levels were increased prior to visual symptoms of pathogenesis when $A$. cassiae spores were applied to seedlings. PAL activity was elevated 3 -fold above uninoculated plants and remained high for several days. Similar results were reported for Alternaria crassa, a fungal bioherbicide that controls jimsonweed (Datura stramonium) [65]. Many examples have been reported and summarized with respect to the correlation of PAL activity with pathogen challenge and plant defense e.g. [66]. Nitrilases are involved in a wide variety of biological processes, some related to plant defense [67] and certain amidohydrolases are reported to contribute to the biosynthesis of auxin, the ubiquitous plant growth hormone [68].

Ammonia and creating an alkaline environment are important in the pathogenisis of some plant pathogens. For example, during colonization of a fungus (C. gloeosporioides) related to $\mathrm{CT}$, ammonia accumulates in the host plant making it more alkaline, thus promoting the activities of extracellular enzymes such as pectate lyase [69]. Similarly, ammonia secretion, modulation of $\mathrm{pH}$ to alkaline conditions and ammonia accumulation have been shown to be critical factors related to the pathogenicity of C. coccodes on tomato (Lycopersicon esculentum) [70]. Plant pathogens and compounds that alter ammonia in a given host, may interact with pathogenesis. 
Although some typical effects of CT (collapsed stems) [38] were observable in the combined treatment of glufosinate and CT, the degree of toxicity of glufosinate on this bioherbicide may have prevented a synergistic interaction response when these two weed control agents were applied at these concentrations together on hemp sesbania. Possibly, by modifying the relative concentrations of glufosinate and CT, i.e., so that the herbicide concentration is lowered (less toxicity to $\mathrm{CT}$ ), while the $\mathrm{CT}$ concentration is raised, might result in synergy. Also, glufosinate could be applied and allowed to be absorbed by the weed for a more extended time, which would effectively reduce the herbicide concentration on the weed surface, and perhaps lower toxicity to CT, thus allowing a higher conidial germination rate, formation of appresoria and infection of this weed host. Synergy is also a concentration dependent phenomenon, and thus altering the concentration ratio of the components may promote or suppress this outcome. Several Colletotrichum species, (C. truncatum, C. gloeosporioides, and C. coccodes) have been reported to have synergistic interactions with various herbicides [51] [71] [72]. Synergy was also reported in combinations of glufosinate and two bacterial bioherbicides on some weeds [29].

\section{Conclusion}

These experiments demonstrated that glufosinate inhibition of growth was expressed in the combination of herbicide and bioherbicide treatment, and the effect on collapsed stem tissue also appeared, but was generally weaker and appeared later in the time course. This could be explained since glufosinate exhibited some growth inhibition to $C$. truncatum when conidia were grown on PDA supplemented with the herbicide. Compared to glufosinate, CT treatment did not cause substantial growth reduction or GS inhibition and ammonia increases until after $\sim 40 \mathrm{~h}$. Important future investigations would include studies on the effects of glufosinate on PAL-glufosinate-CT interactions on this weed as well as investigations on other plant defense enzymes that produce ammonia. The interaction of CT with other herbicides, as demonstrated above with other strains of $C$. truncatum and other Colletotrichum species might also prove beneficial. Examination of glufosinate on conidial germination and appressoria formation would also be appropriate. Such studies will help further elucidate the biochemical and bioherbicidal action of CT on hemp sesbania.

\section{Conflicts of Interest}

The authors declare no conflicts of interest regarding the publication of this paper.

\section{References}

[1] Lorenzi, H.J. and Jeffery, L.S. (1987) Weeds of the United States and Their Control. Van Nostrand Reinhold, New York.

[2] Dowler, C.C. (1992) Weed Survey-Southern States. Proceedings of the Southern Weed Science Society, 45, 392-407. 
[3] King, C.A. and Purcell, L.C. (1997) Interference between Hemp Sesbania (Sesbania exaltata) and Soybean (Glycine max) in Response to Irrigation and Nitrogen. Weed Science, 45, 91-97.

[4] Lovelace, M.L. and Oliver, L.R. (2000) Effects of Interference and Tillageon Hemp Sesbania and Pitted Morningglory Emergence, Growth, and Seed Production. Proceedings of the Southern Weed Science Society, 53, 202.

[5] Bryson, C.T. (1990) Interference and Critical Time of Removal of Hemp Sesbania (Sesbania exaltata) in Cotton (Gossypium hirsutum). Weed Technology, 4, 833-837. https://doi.org/10.1017/S0890037X0002649X

[6] Jordan, D.L., York, A.C., Griffin, J.L., Clay, P.A., Vidrine, P.R. and Reynolds, D.B. (1997) Influence of Application Variables of Efficacy on Glyphosate. Weed Technology, 11, 354-362. https://doi.org/10.1017/S0890037X00043062

[7] Lich, J.M., Renner, K.A. and Penner, D. (1997) Interaction of Glyphosate with Post-Emergence Soybean (Glycine max) Herbicides. Weed Science, 45, 12-21.

[8] Oliver, L.R., Taylor, S.E. and Gander, J.R. (1996) Influence of Application Timing and Rate of Glyphosate on Weed Control in Soybean. Proceedings of the Southern Weed Science Society, 49, 57.

[9] Corbett, J.L., Askew, S.D., Thomas, W.E. and Wilcut, J.W. (2004) Weed Efficacy Evaluations for Bromoxynil, Glufosinate, Glyphosate, Pyrithiobac, and Sulfosate. Weed Technology, 18, 443-453. https://doi.org/10.1614/WT-03-139R

[10] Koger, C.H., Burke, I.C., Miller, D.K., Kendig, J.A., Reddy, K.N. and Wilcut, J.W. (2007) MSMA Antagonizes Glyphosate and Glufosinate Efficacy on Broadleaf and Grass Weeds. Weed Technology, 21, 159-165. https://doi.org/10.1614/WT-06-065.1

[11] Bayer, E., Gugel, K., Hagele, K., Hagenmaier, H., Jessipow, S., Koning, W. and Zahner, H. (1972) Stoffwechselprodukte von Mikroorganismen. Phosphinothricin und Phosphinothricyl-alanyl-alanin. Helvetica Chimica Acta, 55, 224-239. https://doi.org/10.1002/hlca.19720550126

[12] Charudattan, R. and Walker, H.L. (1982) Biological Control of Weeds with Plant Pathogens. Wiley, New York.

[13] TeBeest, D.O. (1991) Microbial Control of Weeds. Chapman and Hall, New York. https://doi.org/10.1007/978-1-4615-9680-6

[14] Hoagland, R.E. (1990) Microbes and Microbial Products as Herbicides. American Chemical Society, Washington DC. https://doi.org/10.1021/bk-1990-0439

[15] Charudattan, R. (2001) Biological Control of Weeds by Means of Plant Pathogens: Significance for Integrated Weed Management in Modern Agro-Ecology. Biological Control, 46, 229-260.

[16] Weaver, M.A., Lyn, M.E., Boyette, C.D. and Hoagland, R.E. (2007) Bioherbicides for Weed Control. In: Updhyaya, M.K. and Blackshaw, R.E., Eds., Non-Chemical Weed Management, CABI International, Cambridge, 93-110. https://doi.org/10.1079/9781845932909.0093

[17] Bailey, K.L. (2014) The Bioherbicide Approach to Weed Control Using Plant Pathogens. In: Abrol, D.P., Ed., Integrated Pest Management. Current Concepts and Ecological Perspectives, Elsevier, San Diego, 245-266. https://doi.org/10.1016/B978-0-12-398529-3.00014-2

[18] Duke S.O., Scheffler, B.E., Boyette, C.D. and Dayan, F.E. (2015) Biotechnology in Weed Control. In: Kirk-Othmer, E., Ed., Encyclopedia of Chemical Technology, John Wiley \& Sons, New York, 1-25. 
https://doi.org/10.1002/0471238961.herbduke.a01.pub2

[19] Hoagland, R.E. and Boyette, C.D. (2016) Controlling Herbicide-Susceptible, -Tolerant and -Resistant Weeds with Microbial Bioherbicides. Outlooks on Pest Management, 27, 256-266. https://doi.org/10.1564/v27_dec_04

[20] Boyette, C.D. (1991) Host Range and Virulence of Colletotrichum truncatum, a Potential Mycoherbicide for Hemp Sesbania (Sesbania exaltata). Plant Disease, 75, 62-64. https://doi.org/10.1094/PD-75-0062

[21] Boyette, C.D., Quimby Jr., P.C., Bryson, C.T., Egley, G.H. and Fulgham, F.E. (1993) Biological Control of Hemp Sesbania (Sesbania exaltata) under Field Conditions with Colletotrichum truncatum Formulatedinan Invert Emulsion. Weed Science, 41, 497-500.

[22] Abbas, H.K. and Boyette, C.D. (2000) Solid Substrate Formulation of the Mycoherbicide Colletotrichum truncatum for Hemp Sesbania (Sesbania exaltata) Control. Biocontrol Science and Technology, 10, 291-300. https://doi.org/10.1080/09583150050044565

[23] Boyette, C.D. and Hoagland, R.E. (2012) Interactions of Chemical Additives, pH and Temperature on Conidia Germination and Virulence of Colletotrichum truncatum, a Bioherbicide for Sesbania exaltata. Allelopathy Journal, 30, 102-116.

[24] Boyette, C.D., Abbas, H.K., Johnson, B.J., Hoagland, R.E. and Weaver, M.A. (2014) Biological Control of the Weed Sesbania exaltata Using a Microsclerotia Formulation of the Bioherbicide Colletotrichum truncatum. American Journal of Plant Sciences, 5, 2672-2685. https://doi.org/10.4236/ajps.2014.518282

[25] Boyette, C.D. (1994) Unrefined Corn Oil Improves the Mycoherbicidal Activity of Colletotrichum truncatum for Hemp Sesbania (Sesbania exaltata) Control. Weed Technology, 8, 526-528. https://doi.org/10.1017/S0890037X00039622

[26] Egley, G.E. and Boyette, C.D. (1995) Water-Unrefined Corn Oil Emulsions Enhance Conidia Germination and Mycoherbicidal Activity of Colletotrichum truncatum. Weed Science, 43, 312-317.

[27] Gressel, J. (2010) Herbicides as Synergists for Mycoherbicides, and Vice Versa. Weed Science, 58, 324-328. https://doi.org/10.1614/WS-09-071.1

[28] Hoagland, R.E. (2001) Microbial Allelochemicals and Pathogens as Bioherbicidal Agents. Weed Technology, 15, 835-857. https://doi.org/10.1614/0890-037X(2001)015[0835:MAAPAB]2.0.CO;2

[29] Christy, A.L., Herbst, K.A., Kostka, S.J., Mullen, J.P. and Carlson, P.S. (1993) Synergizing Weed Biocontrol Agents with Chemical Herbicides. In: Duke, S.O., Menn, J.J. and Plimmer, J.R., Eds., Pest Control with Enhanced Environmental Safety, American Chemical Society, Washington DC, 87-100. https://doi.org/10.1021/bk-1993-0524.ch007

[30] Boyette, C.D., Reddy, K.N. and Hoagland, R.E. (2006) Glyphosate and Bioherbicide Interaction for Controlling Kudzu (Pueraria lobata), Redvine (Brunnichia ovata), and Trumpetcreeper (Campsis radicans). Biocontrol Science and Technology, 16, 1067-1077. https://doi.org/10.1080/09583150600828742

[31] Boyette, C.D., Hoagland, R.E., Weaver, M.A. and Reddy, K.N. (2008) Redvine (Brunnichia ovata) and Trumpetcreeper (Campsis radicans) Controlled under Field Conditions by a Synergistic Interaction of the Bioherbicide, Myrothecium verrucaria, with Glyphosate. Weed Biology and Management, 8, 39-45. https://doi.org/10.1111/j.1445-6664.2007.00272.x

[32] Boyette, C.D., Hoagland, R.E., Weaver, M.A. and Stetina, K.C. (2014) Interaction of 
the Bioherbicide Myrothecium verrucaria and Glyphosate for Kudzu Control. American Journal of Plant Science, 5, 3943-3956. https://doi.org/10.4236/ajps.2014.526413

[33] Boyette, C.D., Hoagland, R.E. and Weaver, M.A. (2008) Interaction of a Bioherbicide and Glyphosate for Controlling Hemp Sesbania in Glyphosate-Resistant Soybean. Weed Biology and Management, 8, 18-24. https://doi.org/10.1111/j.1445-6664.2007.00269.x

[34] Sharon, A., Amsellen, Z. and Gressel, J. (1992) Glyphosate Suppression of an Elicited Response. Plant Physiology, 98, 654-659. https://doi.org/10.1104/pp.98.2.654

[35] Peng, G. and Byer, K.N. (2005) Interactions of Pyricularia setariae with Herbicides for Control of Green Foxtail (Setaria viridis). Weed Technology, 19, 589-598. https://doi.org/10.1614/WT-04-130R.1

[36] Kocher, H. (1983) Influence of the Light on Physiological Effects of the Herbicide, Hoe 39866. Aspects of Applied Biology, 4, 227-234.

[37] Bakerspigel, A. (1953) Soils as a Storage for Fungi. Mycologia, 45, 596-604. https://doi.org/10.1080/00275514.1953.12024301

[38] Hoagland, R.E. (1995) Hydroponic Seedling Bioassay for the Bioherbicides Colletotrichum truncatum and Alternaria cassie. Biocontrol Science and Technology, 5, 251-259. https://doi.org/10.1080/09583159550039710

[39] Boyette, C.D., Hoagland, R.E. and Weaver, M.A. (2007) Biocontrol Efficacy of Colletotrichum truncatum for Hemp Sesbania (Sesbania exaltata) Control Is Enhanced with Unrefined Corn Oil and Surfactants. Weed Biology and Management, 7, 70-76.

[40] Kempers, J. and Kok, C.J. (1989) Re-Examination of the Determination of Ammonium as the Indophenol Blue Complex Using Salicylate. Analytica Chimica Acta, 221, 147-155. https://doi.org/10.1016/S0003-2670(00)81948-0

[41] Cullimore, J.V. and Sims, A.P. (1980) An Association between Photorespiration and Protein Catabolism: Studies with Chlamydomonas. Planta, 150, 392-396.

https://doi.org/10.1007/BF00390175

[42] Ahmad, I. and Malloch, D. (1995) Interaction of Soil Microflora with the Bioherbicide Phosphinothricin. Agriculture, Ecosystems \& Environment, 54, 165-174. https://doi.org/10.1016/0167-8809(95)00603-P

[43] Pline, W.A., Lacy, G.H., Stromberg, V. and Hatzios, K.K. (2001) Antibacterial Activity of the Herbicide Glufosinate on Pseudomonas syringae Pathovar Glycinea. Pesticide Biochemistry and Physiology, 71, 48-55. https://doi.org/10.1006/pest.2001.2556

[44] Albrecht, M. and Kortekamp, A. (2009) The in Vitro Effect of the Herbicide Basta (Glufosinate Ammonium) on Potential Fungal Grapevine Pathogens. European Journal of Horticultural Science, 74, 112-117.

[45] Liu, L., Punja, Z.K. and Rahe, J.E. (1997) Altered Root Exudation and Suppression of Induced Lignification as Mechanisms of Predisposition by Glyphosate of Bean Roots (Phaseolus vulgaris L.) to Colonization by Pythium spp. Physiological and Molecular Plant Pathology, 51, 111-127. https://doi.org/10.1006/pmpp.1997.0113

[46] Tada, T., Kanzki, H., Norita, E., Uchimiya, H. and Nakamura, I. (1996) Decreased Symptoms of Rice Blast Disease on Leaves of bar-Expressing Transgenic Rice Plants Following Treatment with Bialaphos. Molecular Plant-Microbe Interactions, 8, 758-759. https://doi.org/10.1094/MPMI-9-0758

[47] Ahn, I.P. (2008) Glufosinate Ammonium-Induced Pathogen Inhibition and Defense Responses Culminate in Disease Protection in bar-Transgenic Rice. Plant Physiolo- 
gy, 146, 213-227. https://doi.org/10.1104/pp.107.105890

[48] Liu, C.-H., Zhong, H., Vargas, J., Penner, D. and Sticklen, M. (1998) Prevention of Fungal Diseases in Transgenic, Bialaphos-and Glufosinate-Resistant Creeping Bentgrass (Agrostis palustris). Weed Science, 46, 139-146.

[49] Wang, Y., Browning, M., Ruemmele, B.A., Chandlee, J.M., Kausch, A.P. and Jackson, N. (2003) Glufosinate Reduces Fungal Diseases in Transgenic Glufosinate-Resistant Bentgrasses (Agrostis spp.). Weed Science, 51, 130-137. https://doi.org/10.1614/0043-1745(2003)051[0130:GRFDIT]2.0.CO;2

[50] Ismail, B.S., Jokhay, Y. and Omar, O. (1995) Effects of Glufosinate-Ammonium on Microbial Populations and Enzyme Activities in Soils. Microbios, 83, 185-190.

[51] Graham, G.L., Peng, G., Bailey, K.L. and Holm, F.A. (2006) Interactions of Colletotrichum truncatum with Herbicides for Control of Scentless Chamomile (Matricaria perforata). Weed Technology, 20, 877-884. https://doi.org/10.1614/WT-05-026.1

[52] White, J.S. and White, D.C. (1997) Source Book of Enzymes. CRC Press, Boca Raton.

[53] ENZYME. https://enzyme.expasy.org/

[54] Silva, L. and Carvalho, H. (2013) Possible Role of Glutamine Synthetase in the NO Signaling Response in Root Nodules by Contributing to the Antioxidant Defenses. Frontiers in Plant Science, 4, 1-8. https://doi.org/10.3389/fpls.2013.00372

[55] Pageau, K., Reisdorf-Cren, M., Morot-Gaudry, J.F. and Masclaux-Daubresse, C. (2006) The Two Senescence-Related Markers, GS1 (Cytosolic Glutamine Synthetase) and GDH (Glutamate Dehydrogenase), Involved in Nitrogen Mobilization, Are Differentially Regulated during Pathogen Attack and by Stress Hormones and Reactive Oxygen Species in Nicotiana tabacum L. Leaves. Journal of Experimental Botany, 57, 547-557. https://doi.org/10.1093/jxb/erj035

[56] Fagard, M., Launay, A., Clément, G., Courtial, J., Dellagi, A., Farjad, M., Krapp, A., Soulié, M.-C. and Masclaux-Daubresse, C. (2014) Nitrogen Metabolism Meets Phytopathology. Journal of Experimental Botany, 65, 5643-5656.

[57] Liu, G., Ji, Y., Bhuiyan, N.H., Pilot, G., Selvaraj, G., Zou, J. and Wei, Y. (2010) Amino Acid Homeostasis Modulates Salicylic Acid-Associated Redox Status and Defense Responses in Arabidopsis. The Plant Cell, 22, 3845-3863. https://doi.org/10.1105/tpc.110.079392

[58] Camm, E.L. and Towers, G.H.N. (1973) Phenylalanine Ammonia-lyase. Phytochemistry, 12, 961-973. https://doi.org/10.1016/0031-9422(73)85001-0

[59] Jangaard, N.O. (1974) The Characterization of Phenylalanine Ammonia Lyase from Several Plant Species. Phytochemistry, 13, 1765-1768. https://doi.org/10.1016/0031-9422(74)85086-7

[60] Hoagland, R.E. and Duke, S.O. (1983) Relationships between Phenylalanine Ammonia-Lyase Activity and Physiological Responses of Soybean Seedlings to Herbicides. Weed Science, 31, 845-852.

[61] Walker, H.L. (1982) A Seedling Blight of Sicklepod Caused by Alternaria cassiae. Plant Disease, 66, 426-428. https://doi.org/10.1094/PD-66-426

[62] Walker, H.L. and Boyette, C.D. (1985) Biocontrol of Sicklepod (Cassia obtusifolia) in Soybean (Glycine max) with Alternaria cassiae. Weed Science, 33, 212-215.

[63] Walker, H.L. and Riley, J.A. (1982) Evaluation of Alternaria cassiae for the Biocontrol of Sicklepod (Cassia obtusifolia). Weed Science, 30, 651-654.

[64] Hoagland, R.E. (1990) Alternaria cassia Alters Phenylpropanoid Metabolism in Sicklepod (Cassia obtusifolia). Journal of Phytopathology, 130, 177-187. 
https://doi.org/10.1111/j.1439-0434.1990.tb01166.x

[65] Hoagland, R.E. and Boyette, C.D. (1994) Pathogenic Interactions of Alternaria crassa and Phenolic Metabolism in Jimsonweed (Datura stramonium L.) Varieties. Weed Science, 42, 44-49.

[66] Hoagland, R.E. (1996) Chemical Interactions with Bioherbicides to Improve Efficacy. Weed Technology, 10, 651-674. https://doi.org/10.1017/S0890037X00040586

[67] Howden, A.J.M. and Preston, G.M. (2009) Nitrilase Enzymes and Their Role in Plant-Microbe Interactions. Microbial Biotechnology, 2, 441-451.

https://doi.org/10.1111/j.1751-7915.2009.00111.x

[68] Sánchez-Parra, B., Frerigmann, H., Alonso, M.-M., Loba, V.C., Jost, R., Hentrich, M. and Pollmann, S. (2014) Characterization of Four Bifunctional Plant IAM/PAM-Amidohydrolases Capable of Contributing to Auxin Biosynthesis. Plants, 3, 324-347. https://doi.org/10.3390/plants3030324

[69] Prusky, D., McEvoy, J.L., Leverentz, B. and Conway, W.S. (2001) Local Modulation of Host $\mathrm{pH}$ by Colletotrichum Species as a Mechanism to Increase Virulence. Molecular Plant-Microbe Interactions, 21, 1058-1066.

[70] Alkan, N., Fluhr, R., Sherman, A. and Prusky, D. (2008) Role of Ammonia Secretion and $\mathrm{pH}$ Modulation on Pathogenicity of Colletotrichum coccodes on Tomato Fruit. Molecular Plant-Microbe Interactions, 21, 1058-1066. https://doi.org/10.1094/MPMI-21-8-1058

[71] Caulder. J.D. and Stowell, L. (1988) Synergistic Herbicidal Compositions Comprising Colletotrichum truncatum and Chemical Herbicides. U.S. Patent No. 4,775,405.

[72] Wymore, L.A., Watson, A.K. and Gotlieb, A.R. (1987) Interaction between Colletotrichum coccodes and Thidiazuron for Control of Velvetleaf (Abutilon theophrasti). Weed Science, 35, 377-383. 